\title{
Hysterectomy: still a treatment of choice for pelvic pathologies in rural India
}

\author{
Vimal Khunte $^{1}$, Meena Armo ${ }^{1 *}$, Renuka Gahne ${ }^{2}$, Aditya Sisodiya ${ }^{1}$, Shradha Verma $^{1}$
}

\begin{abstract}
${ }^{1}$ Department of Obstetrics and Gynecology, Government Medical College (GMC), Rajnandgaon, Chhattisgarh, India ${ }^{2}$ Department of Pathology, Government Medical College (GMC), Rajnandgaon, Chhattisgarh, India
\end{abstract}

Received: 18 November 2017

Accepted: 18 December 2017

\author{
*Correspondence: \\ Dr. Meena Armo, \\ E-mail: drmeenaarmo@gmail.com
}

Copyright: (C) the author(s), publisher and licensee Medip Academy. This is an open-access article distributed under the terms of the Creative Commons Attribution Non-Commercial License, which permits unrestricted non-commercial use, distribution, and reproduction in any medium, provided the original work is properly cited.

\begin{abstract}
Background: Hysterectomy has always been a subject of controversy in India and increasing rate of unnecessary hysterectomies in young, premenopausal women is cause for concern regarding women's health and rights. The aim of this study is to review and analyse cases of hysterectomy in a rural population and to correlate with underlying factors behind seeking hysterectomy as a treatment of choice for pelvic pathologies.

Methods: This was an ambidirectional observational descriptive study in which 352 women were included who underwent hysterectomy between January 2016 to July 2017 in the Department of Obstetrics and Gynecology, Government Medical College Rajnandgaon and a tertiary care referral hospital of central Chhattisgarh, India.

Results: Majority were between 31-50 years of age group, grandmultipara, uneducated, insured by National health insurance scheme.76.1\% patients had attended medical college hospital to avail free services. $60.5 \%$ took prior treatment from unqualified/ unregistered/registered general practitioners. Erratic use /use of suboptimal dosage of hormones to stop abnormal uterine bleeding, nonspecific antibiotics to treat infection, incomplete treatment and poor compliance were possible reasons behind failure of previous treatments. Abnormal menstruation was the commonest presenting complaint observed in $75.2 \%$. $72.4 \%$ patients refused to come for follow up and reasons were unavailability of transport facility, fear of losing job, loss of daily wages and financial constraints. Commonest indication for hysterectomy was symptomatic fibroid in $32.0 \%$. Total abdominal hysterectomy with bilateral salpingooophorectomy was the most common procedure done in $59.0 \%$. The rate of hysterectomy came out to be $57.6 \%$ which is quite higher than that reported in other studies. Fever was the most common complication encountered in $0.80 \%$.

Conclusions: Despite the remarkable improvement in conservative management and media coverage, hysterectomy still remains the most preferred modality of treatment with excellent satisfaction for pelvic pathologies in rural India.
\end{abstract}

Keywords: Hysterectomy, Pelvic pathologies, Rural India

\section{INTRODUCTION}

The rate of hysterectomy in rural India seems to be on the rise. Uteruses are of no use once they have had children: a common belief amongst poor women living in villages. Untreated gynecological morbidity, barriers to treatment and lack of options available at a primary level may contribute further to unnecessary procedures in younger women. A study conducted in a western state of India
(Gujarat) pointed out that $7-8 \%$ of rural women and $5 \%$ of urban women had already undergone hysterectomy at an average age of 37 years, while newer study from a same state (Gujarat) states, that the only estimate of incidence in India is 20.7 per 1000 woman-years (95\%) at a relatively low mean age of 36 years, which is at least four times higher than the highest global rates such as the United States (5.1 per 1000), Germany (3.6 per 1000) and Australia (3.1 per 1000) [rates in woman-years]. ${ }^{1,2}$ 
However newer and lesser invasive treatment options,are leading to fall in the trends for total abdominal hysterectomy (TAH) with or without salpingooophorectomy in developed world. ${ }^{3}$ The condition is exactly opposite in developing countries, especially in rural population where due to lack of knowledge or social stigma, poor transport and health services, women usually present very late and desire a permanent cure for their problems with requirement of minimal follow up and free treatment in the hospital. ${ }^{4,5}$ The aim of this study is to review and analyse cases of hysterectomy in a rural population and to correlate with underlying factors behind seeking hysterectomy as a treatment of choice for pelvic pathologies.

\section{METHODS}

This ambidirectional observational descriptive study was conducted in the Department of Obstetrics and Gynecology, at Government Medical College Rajnandgaon and a tertiary care referral hospital, which included 352 women out of total 600, who attended OPD for gynecological problems between January 2016 to July 2017.

\section{Inclusion criteria}

- All women, irrespective of their age and parity, who underwent hysterectomy for pelvic pathology

- Any route of hysterectomy

\section{Exclusion criteria}

- Emergency and obstetric hysterectomy

- Malignant condition as an indication

Prior approval from institutional ethical committee was obtained. Base line data were collected from in-patient file. Particulars of previous treatment i.e. treating personnel's, number of visits, details of previous medications taken were obtained by studying referral tickets/prescription letter/OPD slip as brought by the patient. Questionnaires regarding previous treatment, reasons behind attending college hospital for surgery, reasons behind seeking hysterectomy over conservative treatment were asked in detail through face-to-face interviews before surgery. Other determinants like complaints, indications, types of hysterectomy performed, complications and outcome were also recorded and studied. Finally, all parameters were separately analyzed and discussed.

\section{Statistical analysis}

Qualitative data were presented as frequencies and percentages by using SPSS, version 21.

\section{RESULTS}

Table 1: Demographic details $(\mathrm{N}=352)$.

\begin{tabular}{|lrr|}
\hline Variable & No. of women & Percentage \\
\hline$<30$ & 08 & 02.2 \\
\hline $31-40$ & 133 & 38.0 \\
\hline $41-50$ & 116 & 33.0 \\
\hline $51-60$ & 72 & 20.0 \\
\hline $61-70$ & 20 & 06.0 \\
\hline$>70$ & 03 & 0.8 \\
\hline Parity & & \\
\hline $1-3$ & 128 & 36.4 \\
\hline $4-6$ & 212 & 60.2 \\
\hline$>6$ & 12 & 03.4 \\
\hline Socioeconomic status & & \\
\hline Lower middle & 42 & 12.0 \\
\hline Low & 310 & 88.0 \\
\hline Educational status & & \\
\hline Educated up to primary & 82 & 23.0 \\
\hline Uneducated & 270 & 77.0 \\
\hline Insurance status & & \\
\hline Uninsured & 151 & 43.0 \\
\hline Insured & 201 & 57.0 \\
\hline
\end{tabular}

Table 2: Particulars of previous treatment $(\mathrm{N}=352)$.

\begin{tabular}{|c|c|c|c|c|c|}
\hline Percentage & $\begin{array}{l}\text { Treating } \\
\text { Personnel's }\end{array}$ & $\begin{array}{l}>\text { One } \\
\text { visit }\end{array}$ & $\begin{array}{l}\text { Received } \\
\text { symptomatic } \\
\text { /hormonal } \\
\text { treatment }\end{array}$ & Possible reasons for failure treatment & $\begin{array}{l}\text { Reasons for attending } \\
\text { college hospital }\end{array}$ \\
\hline 48 & $\begin{array}{l}\text { Unqualified } \\
\text { /Unregistered } \\
\text { medical } \\
\text { practitioners }\end{array}$ & Yes & Yes & $\begin{array}{l}\text { Erratic use of hemostatics drugs, } \\
\text { progesterone to stop bleeding. } \\
\text { Nonspecific/incomplete } \\
\text { course of antibiotics to treat infections }\end{array}$ & $\begin{array}{l}\text { Can't pay for } \\
\text { Hysterectomy in private } \\
\text { hospitals }\end{array}$ \\
\hline 13 & $\begin{array}{l}\text { Registered } \\
\text { general } \\
\text { practitioners }\end{array}$ & Yes & Yes & 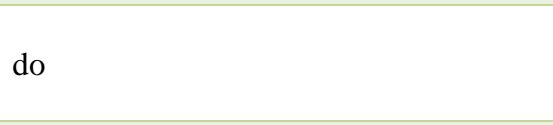 & $\begin{array}{l}\text { Referred to medical } \\
\text { college }\end{array}$ \\
\hline 11 & Gynecologist & Yes & Yes & $\begin{array}{l}\text { Patients left treatment incomplete/poor } \\
\text { compliance }\end{array}$ & Wanted another opinion \\
\hline 28 & None & No & No & & $\begin{array}{l}\text { Directly came to OPD to } \\
\text { avail free services }\end{array}$ \\
\hline
\end{tabular}


Out of the total $352,249(71.0 \%)$ women were between 31-50 years of age group. Majority were grandmultipara, uneducated, from low socioeconomic status, insured by National health insurance scheme (Table 1).

In the present study, $213(60.5 \%)$ patients had prior treatment from unqualified/unregistered/registered general practitioners. Majority of the patients consulted their treating personnel's more than one time. Erratic use or use of suboptimal dosage of hormones to stop bleeding, nonspecific antibiotics to treat infection and poor compliance/incomplete treatment were the possible reasons behind failure of the previous treatment in these patients. $268(76.1 \%)$ patients had attended college hospital to avail free services as they were unable to pay for treatment in private hospital (Table 2).

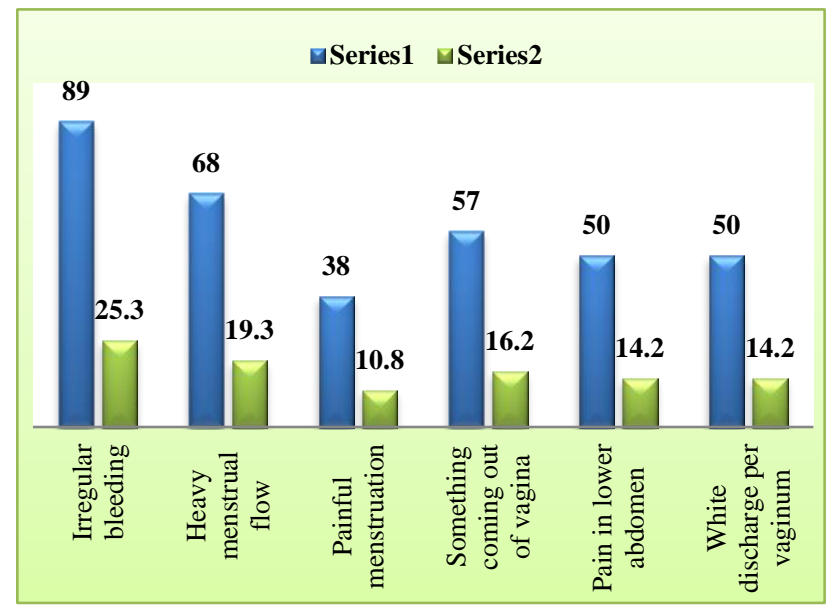

Figure 1: Presenting complaints $(\mathrm{N}=352)$.

The most common presenting complaint in this study was abnormal menstruation in $195(55.3 \%)$, followed by something coming out of vagina in $57(16.1 \%)$ (Figure 1).

Table 3: Reasons behind seeking hysterectomy $(\mathrm{N}=352)$.

\begin{tabular}{|c|c|c|}
\hline Variable & No. & $\%$ \\
\hline Don't want to come for follow-ups & 255 & 72.4 \\
\hline Poor/no transport facility available & 50 & 14.2 \\
\hline Fear of losing job/loss of daily wages & 105 & 30.0 \\
\hline $\begin{array}{l}\text { Coming again and again is } \\
\text { quite expensive and distressing }\end{array}$ & 100 & 28.4 \\
\hline $\begin{array}{l}\text { Want immediate relief from menstrual } \\
\text { problems }\end{array}$ & 215 & 61.0 \\
\hline $\begin{array}{l}\text { Think that uterus is of no use once they } \\
\text { have had children }\end{array}$ & 180 & 51.1 \\
\hline Tired of taking medication & 152 & 43.1 \\
\hline Think that swollen uterus should be removec & 99 & 28.1 \\
\hline Fear of cancer & 92 & 26.1 \\
\hline
\end{tabular}

When conservative management offered, 255 (72.4\%) patients refused to come for follow up and reasons were unavailability of transport facility, fear of losing Job, loss of daily wages, unable to afford treatment expense. (Table 3).

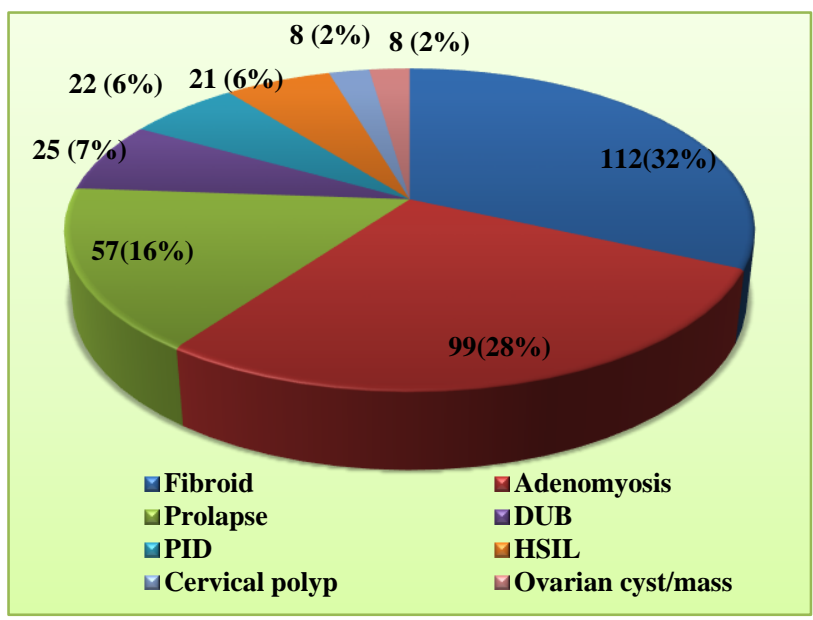

Figure 2: Indications for hysterectomy $(\mathrm{N}=352)$.

Symptomatic fibroid in $112(32.0 \%)$ followed by Adenomyosis in $99(28.1 \%)$ were the most common indications for hysterectomy (Figure 2).

Table 4: Types of hysterectomy performed $(\mathrm{N}=352)$.

\begin{tabular}{|llc|}
\hline Types & $\begin{array}{l}\text { No. of } \\
\text { women }\end{array}$ & $(\%)$ \\
\hline $\begin{array}{l}\text { Total abdominal hysterectomy } \\
\text { (TAH) }\end{array}$ & 65 & 18.4 \\
\hline $\begin{array}{l}\text { Total abdominal hysterectomy with } \\
\text { bilateral salpingo-oopherectomy } \\
\text { (TAH+BSO) }\end{array}$ & 207 & 59.0 \\
\hline $\begin{array}{l}\text { Total abdominal hysterectomy with } \\
\text { unilateral salpingo-oopherectomy } \\
\text { (TAH+ Unilateral SO) }\end{array}$ & 20 & 05.6 \\
\hline Vaginal hysterectomy (VH) & 60 & 17.0 \\
\hline
\end{tabular}

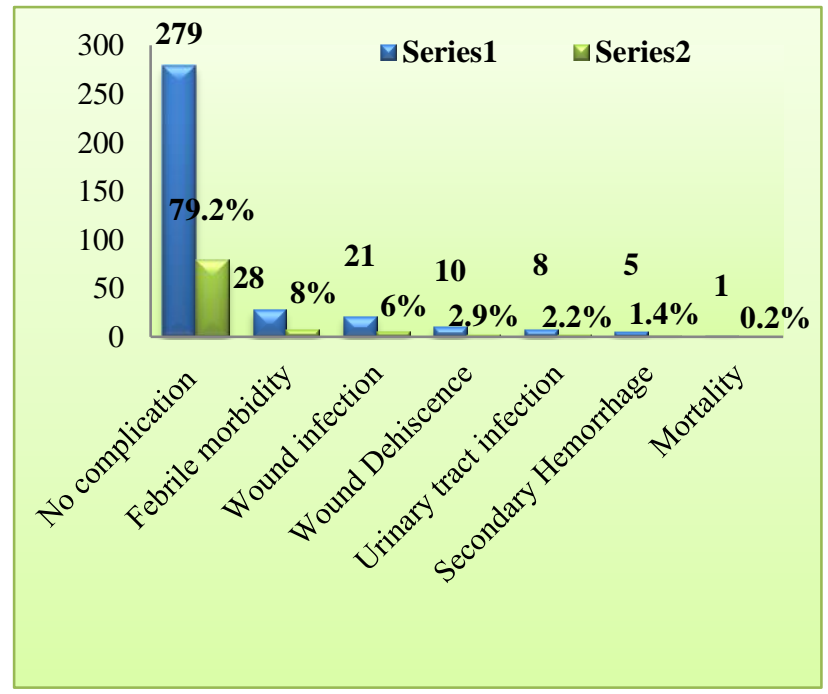

Figure 3: Complications $(\mathrm{N}=352)$. 
Overall, total abdominal hysterectomy with bilateral salpingo-oophorectomy (TAH+BSO) was the most common procedure done in $207(59.0 \%$ ) women (Table 4).

Complications observed in $73(21.0 \%)$ patients, of which the most common complication was fever in $28(08.0 \%)$. Unfortunately, one patient couldn't survive (Figure 3).

\section{DISCUSSION}

This study was conducted at Government Medical College Hospital Rajnandgaon, a newly formed medical college for undergraduates and one of the largest referral centers of central Chhattisgarh. It has highest population of tribal people in India; members of Scheduled Castes (SC) and Scheduled Tribes (ST) make up 50\% of the state and majority of them reside in rural areas.

In the study period from January 2016 to July 2017, total 600 women had attended gynecology OPD for the gynaecological problems, of which 352 women underwent hysterectomies. The rate of hysterectomy came out to be $57.6 \%$ which is quite higher than that reported in a study by Singh A et al, done at govt. medical college Raipur, which is the largest and oldest medical college of our state, where rate was 14.9 to 9.61 per 1000 women per year. The reason may be attributed to lack of equipments for minimally invasive procedures in the department. ${ }^{6}$

Majority of women surveyed for study were from rural background, belong to low socioeconomic status and insured by National health insurance scheme which supports the fact that the incidence of hysterectomy is higher amongst women with relatively lower income group. ${ }^{2}$

The rate of hysterectomy is higher i.e. $37.0 \%$ in women of 31-40 years of age group, while it is $32.0 \%$ in $41-50$ years of age group in our study, which indicates that hysterectomies are still being performed on younger women, it also indicates a high level of gynaecological morbidity and unnecessary use of hysterectomy for treating gynaecological ailments similar as other studies. ${ }^{1,6-8}$

Majority of $60.2 \%$ women were from parity group of 4-6, which was followed by parity group of $1-3$ in $36.3 \%$ similar as data from previous studies that support lower use of contraception in our country. ${ }^{9-11}$

In this study, majority of $76.1 \%$ patients came to our hospital to avail free services as they were unable to pay for treatment in private hospitals. It has been noted that most of the private hospitals in rural areas only treat uncomplicated cases similar as the present study where $13.0 \%$ patients who referred to us were having associated medical problems. Furthermore, poor people too prefer private hospitals over government for the sake of getting immediate care, good care and best facility because it is a common belief that getting anything free is not worthy likewise free health services. Moreover, public facilities lack the infrastructure necessary to perform tests and procedures so that women are forced to visit private hospitals or diagnostic centers to receive services. ${ }^{7}$

Of the total, $60 \%$ patients took prior treatment (alternative/symptomatic/hormonal treatment) from unqualified /unregistered/registered practitioners. After going through the referral tickets/prescription letters/OPD slips brought by the patients, we found that the dosage of haemostatic drugs and progesterone advised to stop bleeding were suboptimum or erratic, same way, antibiotics prescribed to treat infections were nonspecific and inadequate in dosage. This could be the reason behind failure of treatment given previously. Quite similar pattern noted in previous studies, which says that in rural India, regarding women's reproductive healthseeking behaviour, most of the women prefer to tolerate their problems till it becomes intolerable and when they decide they prefer to approach local ASHA/LHV/unqualified/unregistered/rural medical practitioners. These practitioners they in turn with or without giving initial treatment, refer them mostly to a qualified private practitioner to get honorarium. In a majority of cases, the healthcare provider whom women had first contacted had a greater influence on the selection of the hospital. Such perceptions and beliefs constitute a "lay-health culture" which would intervene between the presence of morbidity condition and its necessary treatment. ${ }^{7,12-14}$

In the present study, $75 \%$ women presented with menstrual disturbances similar as previous studies. 9,15,16 Although conservative medical as well as surgical treatments have been thoroughly explained and offered, despite that majority of women demanded hysterectomy and the main reason was unwillingness for follow up due to unavailability of transport facility, fear of losing Job, loss of daily wages and financial constraints. ${ }^{4,5,17}$ However, $51.1 \%$ said that uterus is of no use once they have had children, $28.1 \%$ wanted to remove their swollen uterus and $26.0 \%$ women worried about their risk of developing cancer, which indicates urgent need of health awareness regarding importance of uterus in women's health, amongst rural women and educational training programs for health personnel's to update their knowledge about conservative management. ${ }^{7}$

Symptomatic fibroid (32.0\%) was the most common indication in this study. In review of literature also, fibroid uterus is reported as the most common indication for hysterectomy worldwide. ${ }^{16,18-21}$ However, there has been controversy regarding indications for hysterectomy for benign gynecological diseases in Indian subcontinent. $^{22}$

Of total, only $6 \%$ surgeries were done for premalignant cervical lesions in the study which conclude that rural 
women with cervical malignancy usually present late due to lack of awareness, non availability of adequate screening tests and pathologists. Thus surgery for malignant disease is life-saving, whereas for that benign disease to improve the quality of life, hence hysterectomy is not only a cost-effective but also associated with excellent satisfaction as compared to conservative therapies. $^{21,22}$

Researchers have observed that, National Health Insurance Program (Rashtriya Swasthya Bima Yojana [RSBY] for people living below poverty line in India gives free medical/surgical services for inpatient treatment, but not for outpatient conservative surgeries, they also opine that time is not a constraint for poor, unemployed rural population; who are willing to spend a week in hospital for hysterectomy rather than to spend hefty amounts of money on minimally invasive surgery (laparoscopy) and get back to home early. ${ }^{22,23}$

Total abdominal hysterectomy with bilateral salpingooophorectomy was the most common procedure done in $59.0 \%$ as opposed to another study where rate is higher i.e. $87.3 \% .^{24}$ Although importance of ovarian conservation had been explained thoroughly to the patients, despite the fact none of them body agreed due to fear of developing ovarian cyst/cancer in future.

Overall complication rate in present study was $21.0 \%$ which is higher than the studies done earlier indicates need of strengthening of existing system including monitoring facilities in the hospital. Unfortunately, we lost one patient due to acute respiratory distress syndrome preceded by septicaemia. Thus, hysterectomy is a surgery which has been used and misused, underused, and abused at different times in Gynecology by the provider and beneficiary. ${ }^{25}$

\section{CONCLUSION}

In Chhattisgarh, there is a huge shortage of man power in the public health sector. People from remote areas are very innocent. They are unable to distinguish doctors amongst health workers and quacks thus easily get influenced and misguided. Patients often reach to gynecologist after undergoing unlimited trials and errors of treatment, financially drained out, mentally confused and frustrated, refuse to accept conservative treatment. Finally exasperated with the poor health facilities, hysterectomy appears as a cost-effective prophylaxis, a treatment of choice and permanent solution with excellent satisfaction. However, there is an urgent need for more detailed research on this subject so that it would help government to revise health policies and practices to change rural scenario.

\section{ACKNOWLEDGMENTS}

The authors would like to thank Prof. Dr. R. K. Singh, Dean and Prof. Dr. P. Beck, Medical Superintendent
Government Medical College and Hospital Rajnandgaon, Chhattisgarh for their valuable contribution.

Funding: No funding sources

Conflict of interest: None declared

Ethical approval: The study was approved by the Institutional Ethics Committee

\section{REFERENCES}

1. Desai S, Sinha T, Mahal A. Prevalence of hysterectomy among rural and urban women with and without health insurance in Gujarat, India. Reproductive Health Matters. 2011;19(37):42-51.

2. Desai S, Campbell OMR, Sinha T, Mahal A, Cousens S. Incidence and determinants of hysterectomy in a low-income setting in Gujarat, India. Health Policy and Planning. 2017;32(1):68-78,

3. Whiteman MK, Hillis SD, Jamieson DJ, Morrow B, Podgornik MN, Brett KM, et al. Inpatient hysterectomy surveillance in the United States, 20002004. Am J Obstet Gynecol. 2008;198:34.e1-7.

4. Bower JK, Schreiner PJ, Sternfeld B, Lewis CE. Black-white differences in hysterectomy prevalence: The CARDIA study. Am J Public Health. 2009;99:300-7.

5. Verma D, Verma ML. Trends of hysterectomy in the rural tertiary level teaching hospitals in Northern India. Indian J Obstet Gynecol Res. 2016;3(3):212-5.

6. Singh A, Naik S, Mahilange A. Hysterectomy: changing trends in a tertiary care center. J Evol Med Dental Sci. 2015;4(89):15407-9.

7. Kameswari S, Vinjamuri P. Medical ethics: a case study of hysterectomy in Andhra Pradesh, Hyderabad: National Institute of Nutrition. 2009. Available at kicsforum.net/kics/setdev/hysterectomyethics-in-S-T-for-setdev-final-1.pdf. Accessed 10 September 2017.

8. Rajeshwori BV, Hishikar V. View and review of hysterectomy: a retrospective study of 260 cases over a period of one year. Bombay Hosp J. 2008;50:1.

9. Gupta K, Parmar M. Clinico-histopathological correlation of hysterectomy in rural India: an observational study. Int J Reprod Contracept Obstet Gynecol. 2015;4(2):408-12.

10. Perveen S, Tayyab S. A clinicopathological review of elective abdominal hysterectomy. J Surg Pak (Int). 2008;13(1):26-9.

11. State fact sheet Chhattisgarh: National Family Health Survey-4, 2015-16. Ministry of Health and Family Welfare, Government of India, IIPS (Deemed University) Mumbai. Available at http://rchiips.org/NFHS/factsheet. Accessed 10 September 2017.

12. The unnatural prevalence of hysterectomy in Raipur, Chhattisgarh: A fact-finding report. Available at www.hrln.org/hrln/images/stories/pdf/RR-factfindings-reports-12.pdf. Accessed 7 September 2017.

13. Gupta N. Understanding the reasons for rising numbers of hysterectomies in India: National 
consultation, $12^{\text {th }}$ August 2017: Prayas/Health Watch Trust Chittorgarh, Rajisthan, India. Available at www.prayaschittor.org/pdf/Hysterectomy-report.pdf. Accessed 31 October 2017.

14. Sugathan KS, Vinod M, Robert DR. Promoting institutional deliveries in rural India: the role of antenatal-care services, National Family Health Survey Subject Reports Number 20, December 2001, IIPS Mumbai, India. Available at citeseerx.ist.psu.edu/viewdoc/download?doi=10.1.1. 517.6466\&rep=rep1. Accessed 31 October 2017.

15. Sucheta KL, Manangi M, Madhu KP, Arun BJ, Nagaraj N. Hysterectomy: clinical profile, indications and postoperative complications. Int $\mathbf{J}$ Reprod Contracept Obstet Gynecol. 2016;5(7):20936.

16. Mukhopadhaya N, Manyonda IT. The hysterectomy story in the United Kingdom. J Midlife Health. 2013;4:40-1.

17. Ranson MK, John KR. Quality of hysterectomy care in rural Gujarat: the role of community-based health insurance. Health Policy and Planning. 2001;16(4):395-403.

18. Leung PL, Tsang SW, Yuen PM. Quality assurance subcommittee in Obstetrics and Gynaecology, Hospital Authority, Hong Kong. An audit on hysterectomy for benign diseases in public hospitals in Hong Kong. Hong Kong Med J. 2007;13:187-93.

19. Sait K, Alkhattabi M, Boker A, Alhashemi J. Hysterectomy for benign conditions in a university hospital in Saudi Arabia. Ann Saudi Med. 2008;28:282-6.

20. Singh A, Arora KA. Why hysterectomy rate are lower in India. Indian $\mathbf{J}$ Community Med. 2008;33(3):196-7.

21. Shrivasatva D, Chaudhry P. Happy hysterectomy? quality of life after in rural women of central India. Global J Med Res: E Gynecol Obstet. 2015;15(3).

22. Sharma C, Sharma M, Raina R, Soni A, Chander B, Verma S. Gynecological diseases in rural India: a critical appraisal of indications and route of surgery along with histopathology correlation of 922 women undergoing major gynecological surgery. J Midlife Health. 2014;5(2):55-61.

23. Department of Health and Family Welfare. RSBY. Available http://cgdemo.nic.in/PMFBY/cghealth/cghealth17/in dex.html . Accessed 30 October 2017.

24. Bala R, Devi KP, Singh CM. Hysterectomy: changing trends over past 5 years in RIMS, Imphal, Manipur J Med Society. 2015;29(1):4-7.

25. Magon N, Divakar H, Kriplani A. Editorial: the use, misue, and abuse of hysterectomy. J Mid-Life Health. 2013;4(1).

Cite this article as: Khunte V, Armo M, Gahne R, Sisodiya A, Verma S. Hysterectomy: still a treatment of choice for pelvic pathologies in rural India. Int J Reprod Contracept Obstet Gynecol 2018;7:536-41. 